\title{
The position of the state in global capitalism: a Polanyian perspective
}

Keywords: Karl Polanyi, hegemony, global economy, the state

\begin{abstract}
The aim of the article is to analyze the changing position of the state in the capitalist world economy form the perspective of Karl Polanyi's political theory. The main thesis of the article is that the position of the state largely depends on the character of rules constituting global political economy. Three world regimes were singled out (gold standard, Bretton Woods system, and hyperglobalization), and the position of the state within each system was analyzed. If we agree with Robert Cox that each world order is a product of ideas, institutions and power relations, then we may expect the institutional structure of the world economy to evolve following the changes in the underlying constellation of ideas and social forces.
\end{abstract}

The present article is an attempt to analyze changes in the position of the state in a global capitalist system from the point of view of institutional political economy inspired by Karl Polanyi's writings ${ }^{1}$. The per-

* ORCID ID: https://orcid.org/0000-0001-9928-1161; Ph.D., employed at the Department of Political Theory and Political Thought of the Faculty of Political Science and International Studies at the University of Warsaw. He is interested in political philosophy and institutional political economy. Email: m.kassner@uw.edu.pl

1 The article was written within a research project "Market and Politics. A Study of Political Philosophy of Karl Polanyi”, financed by the National Science Centre (registration number: 2016/20/S/HS5/00556). I would like to thank Sławomir Czech, Ph.D. for his comments on the first version of the text. 
spective proposed here differs both from the approach of international economics and from the majority of Marxist approaches. Differently from the mainstream economics, the institutional approach assumes that the state's condition in global economy cannot be understood without considering political and ideological factors, in particular the struggle for hegemony between the advocates of economic liberalism and their opponents. Contrary to many varieties of Marxism, institutionalism rejects explanations referring to the supposed logic of the capitalism, no matter if this logic is explicated in the categories of the law of the falling rate of profit, the imperative of unlimited accumulation of capital or in any other way. The global evolution of capitalism as well as the position of the state in this system is the resultant of the fundamental institutional contradiction between the requirements of domestic social protectionism and the attempt to create the world market system eliminating successive barriers for the flow of people, commodities and capital. The state's ability to pursue a sovereign economic policy is an institutional variable which depends on the character of rules making up the international economic order.

I adopt the following order of argumentation. First, I will make a reconstruction of the main assumptions of institutional tradition in international political informed by ideas of Karl Polanyi. Next I will present an outline of the history of international order inspired by this perspective. To simplify the argumentation, three world orders were distinguished, namely the system of the gold standard, the order set up at the Bretton Woods conference and the regime of hyper-globalization. A special emphasis will be placed on the position of the state in these three orders. Summing up the article, I present the main conclusions concerning institutional conditions of the state's position in global market economy.

\section{Karl Polanyi and international political economy}

Karl Polanyi is best known as the author of The Great Transformation ${ }^{2}$ published for the first time in 1944. In that book, he argued that economic order based on the gold standard was impossible to reconcile with a democratic government. Global expansion of markets, expressed by the system of the gold standard, had destabilizing social consequences. At

2 Cf. K. Polanyi, The Great Transformation. The Political and Economic Origin of Our Time, foreword by Joseph Stiglitz, with a new introduction by Fred Block, Beacon Press 2001. 
the same time democracy created a space for the political organization of social groups which were most affected by this process. The final effect of this contradiction between domestic political institutions and international economic institutions - or using the contemporary terminology, between democracy and globalization - was the breakup of the system of the gold standard. Polanyi's work is by no means a systematic theoretical treatise. The author's original concepts are embedded in the historical narrative on the emergence and collapse of liberal capitalism. For our considerations of key importance are three aspects of Polanyi's approach, namely the institutional view on the character of the world order, the idea of the double movement and his observations on the role of the hegemon in international policy.

According to Karl Polanyi, international order is an institution sui generis $^{3}$. The functioning of the world economy is based on a number of formal and informal rules. An example of the former are international treaties as well as the functioning of international organizations based on them. Informal rules can be observed in the efforts made by governments and central banks to stabilize the international order such as loans given for strategic purposes or coordination of macro-economic policies. The existence of more or less clearly formulated rules is the main reason why we can use such terms as system, regime or order in relation to the world economy. Obviously, those rules, composing the global order, are established and maintained by national states. Not all states get an equal share in the creation of international institutions. In the science on international relations, the state which has the greatest influence on institutionalization of the world order is called a hegemon ${ }^{4}$. Although

3 Ibidem, p. 18. As Polanyi explains, "unless we defer to the uncritical practice of restricting the term «organization» to centrally directed bodies acting through functionaries of their own, we must concede that nothing could be more definite than the universally accepted principles upon which this organization [global economy - M.K.] rested and nothing more concrete than its factual elements".

4 The view saying that in order to ensure a stable international order the involvement of the dominating power is necessary is called the theory of hegemonic stability. It was originally formulated by an economist Charles Kindelberger, and next developed by the theoreticians of international relations such as Robert Gilpin and Robert Keohane. Cf. R. Keohane, After Hegemony. Cooperation and Discord in World Political Economy, Princeton University Press 1984, pp. 31-46. It should be added that the hegemonic stability theory does not have much in common with Robert Cox's attempt to apply Antonio Gramsci's theory of hegemony to the field of international relations. The present article mainly makes use of the other approach. On the differences between the American school and the British school in international political economy, including a different use of the category of hegemony, see: B.J. Cohen, International Political Economy. An Intellectual History, Princeton University Press 2008, pp. 66-94. 
international regimes are a creation of the states, the rules which were once established limit the freedom of governments to pursue a macroeconomic policy. For this reason, the existing international order can be considered one of the factors determining the state's position in the global market economy.

The attitude of the states with regard to the preferred form of international order depends on the configuration of social forces and on which economic ideology will manage to achieve the hegemonic position. Karl Polanyi thought that the shape of the international order is affected by the special political dynamics which he called the double movement. The double movement meant the clash of two opposing tendencies, namely economic liberalism and social protectionism. Economic liberalism aims at removing all barriers for the flow of people, commodities, services and capital. "Liberal capitalism - Polanyi explains - is based on one simple dogma: purchasing and selling abroad, giving credits and taking loans, as well as exchanging foreign currencies take place between individuals as if they were the citizens of one and the same state"5. This ideology represents the interests of financiers and a part of the capitalist class oriented at conquering international markets. Social protectionism aims at protecting the land, labour and organization of production from the negative consequences of marketization of economy. The protectionist reaction can take different ideological forms, beginning with nationalism through social democracy to contemporary anti-globalization movements. Its social background is composed of the working class, classes connected with the land and in part also the domestic capital seeking protection from international competition.

The world order is then a reflection of the international importance of particular countries, a configuration of social forces inside them and the dominant ideology. Such mutual adjustment of forces, ideas and institutions was called hegemony by Robert Cox ${ }^{6}$. Hegemony differs from domination in being largely based on consensus. A given world order is, therefore, hegemonic to the extent its basic assumptions are voluntarily accepted by the states. It should be admitted that Karl Polanyi did not make use of the concept of hegemony. This category derives from the writings by an Italian Marxist Antonio Gramsci and it is from there it

5 K. Polanyi, Universal Capitalism or Regional Planning, [in:] M. Cangiani, C. Thomasberger (ed.), K. Polanyi, Economy and Society. Selected Writings, Cambridge University Press 2018, p. 237.

6 R. Cox, Social forces, states and world orders: beyond international relations theory, [in:] R. Cox, T. Sinclair, Approaches to world order, Cambridge University Press 1996, p. 104. 
entered the science of international relations ${ }^{7}$. Nevertheless, as noticed by Giovanni Arrighi and Beverly Silver, The Great Transformation can be read as a classic work on belle époque of the British hegemony ${ }^{8}$. The narrative presented in this book about the birth and fall of the system of the gold standard is a heuristic model which can be used in the analysis of the successive world orders 9 .

\section{From the gold standard to hyper-globalization}

\section{The gold standard and free trade}

The first global economic order known from history was shaped in the $19^{\text {th }}$ century ${ }^{10}$. It was based on two foundations: the ideology of free trade and the gold standard. Great Britain adopted the gold standard in 1718 almost by accident. Isaak Newton, who was then the Master of the Royal Mint, established a too low price for silver, the result of which was that silver coins almost completely disappeared from circulation ${ }^{11}$. With time, the standard based on gold also got accepted by other countries for which economic transactions with Great Britain and access to the British capital market were of importance. At the beginning of the $20^{\text {th }}$ century nearly all states which were economically important guaranteed convertibility of their currencies into gold ${ }^{12}$. The second institution of the international economic system was free trade. It was adopted in Great Britain when in 1846 so called "corn laws", which imposed a duty on imported corn, were repealed. The idea of free trade proved to be much less lasting than the gold standard. In Germany from Bismarck's times industrialists and junkers opted for customs tariffs, which was later known in history

7 Cf. R. Cox, Gramsci, Hegemony, International Relations: An Essay in Method, «Millennium - Journal International Studies»1983, vol. 12, No. 2, pp. 162-175.

8 Cf. G. Arrighi and B.J. Silver, Polanyi's «Double Movement»: The Belle Epoques of British and U.S Hegemony Compared, «Politics and Society» 2003, vol. 31, Issue 2.

9 Polanyi's views exerted influence on researchers dealing with international political economy such as Fred Block, John Gerald Ruggie, Eric Helleiner, Robert Cox and Stephan Gill. Karl Polanyi's selected theses were also undertaken by economists specializing in the problems of international finances and trade such as Dani Rodrick and Barry Eichengreen. The analysis presented below makes use of the findings of both these traditions.

10 Cf. F. Block, Capitalism The Future of Illusion, University of California Press 2018, pp. 146-175.

11 B. Eichengreen, Globalizing Capital. A History of the International Monetary System, Princeton University Press 2019, p. 5.

12 Eichengreen says that at the end of the $19^{\text {th }} \mathrm{c}$. Spain was the only European country outside the gold standard. Cf. B. Eichengreen, Globalizing Capital..., p. 6. 
as the coalition of rye and iron. An analogous turn towards protectionism took place in the United States under the effect of Alexander Hamilton's ideas proclaiming a need to protect infant industries ${ }^{13}$. Nevertheless, the international economic system shaped in the second half of the $19^{\text {th }}$ century in many respects belongs to most liberal in history. This partly follows from the fact that few barriers existed then for the flow of people and capital. Above all, however, the liberal character of the international order was a product of the ideological hegemony of liberalism and the dominant position of Great Britain on the international arena.

The classic model of gold standard was developed by a Scottish philosopher David Hume. As explained by Barry Eichengreen, it was one of the first equilibrium models in the history of economics ${ }^{14}$. The gold standard requires the state to establish a permanent parity according to which its currency will be exchanged for gold. Next, the process of regulation works by itself. When the state shows a surplus in transactions abroad, we can expect an inflow of gold to the country. If the state shows a deficit, gold floats away abroad. Thanks to simple dependences the work of an automatic adjustment mechanism is possible, which restores the balance of payments. The outflow of gold will lead to a decrease in prices and wages in the country, which will be followed by improved competitiveness of domestic enterprise on international markets. Low prices make the goods produced in the country cheaper than their counterparts from the countries of a stronger currency. As a result, gold will start flowing into the country again, and the deficit of the balance of payments will disappear. This model was extended by economists with successive elements such as international capital flow, central banks and interest rates ${ }^{15}$. Hume's mechanism assumed that the necessary adjustments take place automatically, which was in agreement with the ideology of market self-regulation. Support for the gold parity was not, however, limited only to the advocates of market orthodoxy. As pointed out by Karl Polanyi, at the turn of the $19^{\text {th }}$ and $20^{\text {th }}$ centuries this institution enjoyed the acceptance of almost all political options ${ }^{16}$. "Belief in the gold standard" - claims Polanyi - "was the faith of the age" 17 .

13 Cf. D. Rodrik, The Globaliztion Paradox. Why Global Markets, States and Democracy Can't Coexist, Oxford University Press 2011, pp. 26-34.

14 Cf. B. Eichengreen, Globalizing Capital..., p. 23.

15 Ibidem.

16 Cf. K. Polanyi, The Great Transformation..., p. 26.

17 Ibidem. 
The practice of the gold standard considerably departed from what the mechanism of self-regulation described by David Hume postulated. As argued by Barry Eichengreen, international flows of gold were much smaller than it could have followed from the deficits in commercial exchange $^{18}$. In practice, the gold standard proved not so much an automatic adjustment mechanism but rather a complex social institution based on a number of formal and informal rules. Its efficient functioning was possible thanks to the common conviction that central banks and governments would undertake activities necessary to ensure convertibility of the currency into gold. Such conditions existed before World War I, when the economic policy was largely isolated from the postulates of working classes. As indicated by Eichengreen, at that time international movements of capital promoted stabilization of the system of gold currency since the investors assumed that governments would run the policy consistent with the interests of the financiers ${ }^{19}$. What is more, governments and central banks of the most important states were willing to grant loans to each other and coordinate macro-economic policies with the aim of maintaining the binding gold parities ${ }^{20}$. The situation was reversed in the period between the world wars. The establishment of democratic regimes and participation of workers' parties in governments weakened the commitment to a balanced budget and currency stability. In particular, as was shown by the example of Great Britain's failed attempt to return to the gold parity from before the war, it was impossible any longer to count on the working classes to accept the cuts in governments' expenditures and wage decreases, which were necessary to restore the competitiveness of the economy on the international arena ${ }^{21}$. This was the essence of the contradiction between democracy and the international system based on the gold standard, which is the central axis of narrative developed by Karl Polanyi in The Great Transformation.

The economic history of the 1920's and 1930's is a record of failed attempts at reconciling contradictory imperatives of democratic politics and the international economic system based on the gold standard.

\footnotetext{
18 B. Eichengreen, Globalizng Capital..., p. 23.

19 Ibidem, pp. 25-29.

20 Coordination of macro-economic policy consisted in central banks of particular countries imitating the activities of the Bank of England. An example of international solidarity can be the crisis of 1890, when the banks of Russia and France granted considerable loans enabling Great Britain to keep the parity of gold. Cf. B. Eichengreen, Globalizing capital..., pp. 30-31.

21 Cf. D. Rodrik, The Globalization Paradox..., pp. 40-44.
} 
Hume's adjustment mechanism required flexible labour markets which have become politically unsustainable. At the same time, the international economy without the gold standard seemed unimaginable. The economic crisis of 1929 accelerated the collapse of the gold parity ${ }^{22}$. Successive countries gave up convertibility of their currencies into gold. Great Britain abandoned the gold standard in 1931 and the United States did it two years later ${ }^{23}$. Even those countries which formally kept the gold parity, such as Germany and Eastern European countries, introduced strict restrictions in currency convertibility. Customs, tariffs and currency devaluations became a commonly used instruments of economic policy. International economic cooperation was replaced by striving for autarky and an increasingly visible armaments race. Karl Polanyi probably exaggerated when he claimed that "the snapping of the golden thread was the signal for a world revolution" 24 . However, there is no doubt that each reliable explanation of the 1930's crisis must consider the shortcomings of the international order created under the auspices of economic liberalism.

The gold standard functioned stably in the reality of a minimal state and a limited voting rights but it proved impossible to reconcile with democracy giving strong representation to working classes. The major mechanisms that disciplined the governments under the gold standard were capital flights and a threat of cutting the country off from international capital market. More brutal measures were occasionally applied towards peripheral countries. An example can be entrusting an international agency with the task of tax collection in the Ottoman Empire to satisfy the claims of creditors ${ }^{25}$. At the same time, the existence of central banks and the possibility of paper money emission made it possible to a certain extent to soothe the turbulences connected with the functioning of the gold standard.

\section{The Breton Woods system}

The explanation proposed by Karl Polanyi of the causes of the breakdown of capitalism in the period between the world wars certainly is not

22 Cf. B. Eichengreen, Globalizing Capital..., pp. 69, ref. 36.

23 Strictly speaking, the United States preserved the parity of the dollar in relation to gold but they introduced restrictions on convertibility and enforced the purchase of gold. Nevertheless, as a result of those activities the gold standard understood as an institution aimed to ensure the freedom of capital flows and stability of currency rates ceased to exist.

24 K. Polanyi, The Great Transformation..., p. 29.

25 D. Rodrick, Globalization paradox..., p. 38. 
complete $^{26}$. Nevertheless, the central thesis of The Great Transformation concerning the incompatibility of democracy and the gold standard, the thesis which Karl Polanyi shared with John Maynard Keynes, played an important role in the post-war reconstruction of the economy. The Bretton Woods system, which was supposed to replace the discredited interwar order, reflected an altered geopolitical and ideological situation. The importance of change went beyond merely moving from Pax Britannica to Pax Americana. The shift on the seat of the hegemon of the global economy coincided with the change of the view on the goals that the international economic order was supposed to serve. As explained by John Gerald Ruggie, "contrary to nationalism of the thirties, it would be multilateral in character; unlike the liberalism of the gold standard and free trade, its multilateralism would be predicted upon domestic interventionism"27. Socially embedded liberalism - the expression referring to Polanyi's terminology and coined by Ruggie to convey the essence of the new order - connected both components of post-war compromise ${ }^{28}$.

The post-war economic order consisted of a number of inter-related elements. Signatories of the Bretton Woods agreement committed themselves to aiming at trade liberalization within the system of multilateral trade agreements. Such international institutions as the World Bank and the International Monetary Fund were established and their task was to grant loans to developing countries and to support the states which had difficulties restoring balance of payments. The United States committed itself to keeping the parity of the dollar in relation to gold, while other countries established the parity of their own currency in relation to the dollar. The currency rates were to be pegged in principle but the possibility of devaluation in the situation of fundamental disequilibrium was allowed. The state wishing to perform such an operation had to notify the International Monetary Fund about it earlier. At the same time the Bretton Woods system provided for a number of provisions which facilitated a sovereign macro-economic policy. Although the signatories

26 Giovanni Arrighi and Beverly Silver argue that the unilateral adoption of the policy of free trade by Great Britain was possible only due to India's contribution to the balance of payments, which was not noticed by Karl Polanyi. Cf. G. Arrighi and B.J. Silver, Polanyi's «Double Movement»: The Belle Epoques of British and U.S Hegemony Compared, "Politics and Society» 2003, vol. 31, Issue 2, pp. 335-336.

27 J.G. Ruggie, International Regimes, Transactions and Change: Embedded Liberalism in the Postwar Economic Order, «International Organization» Spring 1982, No. 36, p. 393.

28 Karl Polanyi himself was very critical of the Bretton Woods agreements. Cf. K. Polanyi, British Labour and American New Dealers, [in:] K. Polanyi, Economy and Society..., pp. 226-230. 
of the agreements committed themselves to restoring full convertibility of currencies on current account, at the same time they kept their right to control capital flows. That solution gave the countries a considerable dose of freedom in their domestic policy ${ }^{29}$. Trade agreements left strategic sectors of the economy untouched and did not stand in the way of the state's active industrial policy. The international financiers were slowly rebuilding their position after the war and their activities were not a threat to governments.

A number of factors contributed to the collapse of the Bretton Wood system. The post-war reconstruction brought revival of trade and international investments. Restoration of full convertibility of currencies on the account of current transactions facilitated trade but also made it more difficult to control international movements of capital ${ }^{30}$. Pegged currency rates had not been adjusted even when there were considerable deficits. Coordinated devaluation proved an extremely difficult task, partly because information on such plans might get to the financial markets. As a result, as argued by Barry Eichengreen, the Bretton Woods system was deprived of an efficient adjustment mechanism ${ }^{31}$. The fact that it lasted was possible thanks to the international economic cooperation $^{32}$. Ultimately, the collapse of the Bretton Woods system was determined by the Vietnam war. The Bretton Woods system was based on the assumption that the United States preserved a constant parity of the

29 Controlling capital flows enables the states to keep lower interest rates without worrying whether the capital flows away to the states of higher interest rates. This solution enabled the policy of full employment without the risk of excessive weakening of the currency. Besides, the capital had less possibility to escape to the countries where less restrictive regulations, tax regulations and social standards were in force. The policy of controlling capital flows limited then the possibility of using blackmail by capitalists threatening to transfer the production to another place. Thus it strengthened the position of the working class (and the industrial capital) in relation to the financial capital. On the role of controlling capital in the post-war order and on the need to return to such a policy, cf. J. Crotty, G. Epstein, In Defence of Capital Controls, «Socialist Register» 1996, vol. 32, pp. 118-149.

30 The European countries managed to restore currency convertibility on the current account in 1958. This success limited, however, the effectiveness of control on the capital account. Overstated or understated amounts on invoices from export or import of goods and services could be used as a shield to take the capital out of the country. Cf. B. Eichengreen, Globalizing Capital..., pp. 106 and 113.

31 Ibidem, p. 125.

32 This cooperation comprised, for example, such activities as coordinated intervention of European countries and the United States on the gold market known as London Gold Pool, as well as Germany's agreement to revaluate the currency with the aim of increasing the competitiveness of American economy. Cf. B. Eichengreen, Globalizing capital..., pp. 120-123. 
dollar in relation to gold. In the face of the increasing trade deficit and higher war expenditures, keeping the gold parity required drastic cuts of expenditures in domestic policy and that was something the United States did not intend to do. Faced with American military interventions in the Far East the European countries and Japan decided that they were not interested in supporting the dollar any further. The decision on suspending convertibility of the dollar into gold was taken on 15 August 1971 by the administration of president Richard Nixon. This date is considered to be the symbolic end of the Bretton Woods system.

The institutional architecture designed at the conference in Bretton Woods was a significant part of the golden age of capitalism. The solutions developed then enabled the development of welfare states and gave considerable freedom to the third world countries in experimenting with various political systems. What is more, as pointed out by Eric Helleiner, the Bretton Woods order was designed in such a way that the states of various economic systems could cooperate within its framework ${ }^{33}$. It was initially assumed that the socialist block countries could be interested in participating in that agreement. And so the Bretton Woods system allowed, at least in principle, for the possibility of adopting a non-capitalist path of development. The main mechanisms guaranteeing policy autonomy of individual states included capital controls and limited liberalization of trade. The key spheres of life such as intellectual property rights, agricultural production or public services fell outside the scope of trade agreements. Liberalization of trade mainly consisted of removing customs barriers and it did not significantly restrict the possibility of the state pursuing an active industrial policy. Besides, the existence of a two-block system increased the possibility of developing countries pursuing independent policy. The major factor disciplining the states was an obligation to keep the parity of the dollar in relation to gold (in the case of the United States) and national currencies in relation to the dollar (in the case of the other countries). Retrospectively, it should be acknowledged that the Bretton Woods system ensured more freedom to the states in shaping their interior economic policy as compared to any type of international economic order known from history.

33 Cf. E. Helleiner, Life and Times of Embedded Liberalism: Legacies and Innovations Since Bretton Woods, «Review of International Political Economy» 2019, vol. 26, No. 6, p. 1116. 


\section{The regime of hyperglobalization ${ }^{34}$}

The contemporary triumph of globalization is a consequence of the gradual dismantling of the post-war economic order. After the United States suspended the convertibility of the dollar into gold, the majority of states adopted floating exchange rates. Floating exchange rates, although susceptible to excessive fluctuations and speculative attacks, made it possible to pursue an active macro-economic policy. With time, however, the other elements of the Bretton Woods system got eroded. The role of the United States in the global economy underwent a change: the state aimed at export became the main center of financial services and the importer of capital. A restrictive monetary policy started by Paul Volcker, head of the Chairman of the Federal Reserve contributed to an increase in unemployment and the weakening of the power of the working class ${ }^{35}$. The ideology of economic liberalism - under the banner of neoliberalism, the Washington consensus or the doctrine of the inevitability of globalization - began to grow in importance again. The International Monetary Fund and the World Bank became the guardians of the new orthodoxy by making loans dependent on restrictive policy of budget cuts and pro-market structural reforms. Liberalization of trade extended into so far untouched areas such as services, intellectual property rights, or agricultural produce. The new regulations imposed considerable restrictions on conducting an independent industrial policy. Some treaties provided for the possibility for international corporations to sue the states within the framework of a special arbitration mechanism. Successive barriers were also removed in the field of capital flows, including direct foreign investments and short-term portfolio transactions. International corporations obtained the power to locate their production in the countries of lower social and ecological standards while the international high finance enjoyed almost unlimited freedom in their access to local capital markets. The states of South America such as Argentina and Brazil tried to mitigate excessive fluctuations of the rates by pegging their currency to the dollar, while European countries aimed at a currency union ${ }^{36}$. The effect was the establishment of the Eurozone, which

34 I took the concept of hyperglobalization from D. Rodrick. It is supposed to indicate the difference of the new order in comparison to the Bretton Woods system, which was a regime of limited globalization. Cf. D. Rodrik, Globalization Paradox..., p. xviii.

35 Cf. J. Crotty, G. Epstein, In Defence of Capital Controls, «Socialist Register» 1996, vol. 32, p. 128.

36 By creating currency boards such countries as Brazil, Argentina or Turkey gave up a sovereign monetary policy for the benefit of stability which was expected to be brought by binding 
- according to some critics - has the same drawbacks which Karl Polanyi attributed to the gold standard ${ }^{37}$.

The position of a state in the system of hyperglobalization is determined by two factors. The first one is a greater role of financial markets and international mobility of capital. Factory owners obtained a new tool, namely a threat to relocate the production. Lowering the CIT tax in OECD countries together with departing from the policy of collective bargaining in a number of countries can be interpreted as a sign of a strengthened position of capital in relation to the state and the working class ${ }^{38}$. At the same time countries became more dependent on financial markets, both due to their own financial needs and the fear of destabilizing consequences of the capital outflow. In this context Wolfgang Streeck puts a thesis that contemporary states must maneuver between two groups of stakeholders ${ }^{39}$. The first group includes the voters who demand employment stability and social rights, while the other are international investors calling for budget discipline and low inflation. A striking example of changes in the relations between the states and private entities is an increase of the importance of rating agencies such as Standard\& Poor and Moody's, whose tasks include evaluating the states from the point of view of the interests of international capital.

The next process leading to the weakening of the state's role concerns the implementation of several legal restrictions, which Stephan Gill calls new constitutionalism ${ }^{40}$. This group of measures includes the regulations

their currencies with the dollar. This solution resembled the gold standard and it fell for the same reason: austerity policy necessary to keep the stability of the currency proved too costly. Cf. B. Eichengreen, Globalizing Capital..., p. 198.

37 The comparison follows from the fact that both systems enforce the austerity policy as the main adjustment mechanism. The main difference is that the Euro is a common currency and not an international monetary system. In some respects, this solution is much worse than the gold standard since it does not provide for the possibility of leaving the currency union while in the conditions of the gold standard suspending the convertibility of the currency did not present any greater problem. More on the analogy between the Euro and the gold standard, see: W. Streeck, Buying Time. The Delayed Crisis of Democratic Capitalism, London and New York 2014, pp. 174-177.

38 D. Rodrick, Populism and the Economics of Globalization, NBER Working Paper 2017, https:// www.nber.org/system/files/working_papers/w23559/w23559.pdf (5.04.2021).

39 W. Streeck, Buying Time..., pp. 79-90.

40 Cf. S. Gill, Market civilization, new constitutionalism, and the world order, [in:] S. Gill, A. Claire Cutler (eds.), New Constitutionalism and the World Order, Cambridge University Press 2014, pp. 29-45. Old constitutionalism is understood by Gill as an attempt to limit anarchy in international relations by placing them within legal frames. New constitutionalism, on the other hand, is supposed to consist of using international and constitutional law to institutionalize neoliberal economic solutions. 
strengthening the independence of central banks, monetary unions currency boards as well as fiscal rules written into national constitutions or to international agreements such as the Maastricht Treaty. Intellectual property rights are protected by the agreements established within the World Trade Organization (Agreement on Trade Related Aspects of Intellectual Property Rights, so-called TRIPS). The possibility of free investment of the capital is, on the other hand, the subject of over 3,000 bilateral investment agreements (Bilateral Investment Treaties, so-called BITS). The freedom of the movement of goods is guaranteed by World Trade Organization as well as in various regional agreements such as NAFTA, MERCOSUR, or UE. At the same time, the regulations concerning the environment and the workers' rights in international law have much weaker protection than intellectual property rights and guarantees of free movement of goods and capital. As argued by Gill, the aim of the new constitutionalism is to curb the protectionist movement understood by Karl Polanyi as aiming at the protection of the society from destabilizing consequences of the free market utopia. This aim is to be served by the freezing of neoliberal policies through their institutionalization on the constitutional level and in international law, which are relatively resistant to democratic pressure.

In the regime of hyperglobalization the ability of the state to pursue an active domestic policy got considerably weaker, which resembles the gold standard. At the same time, like in the case of the Bretton Woods system, the order of hyperglobalization is multilateral and is based on international law. At the beginning of the $21^{\text {st }}$ century, we can observe more and more symptoms of departure from this order. The examples include Brexit, trade wars with China, or failed negotiations concerning the agreement on the Transatlantic Partnership (TTIP) and further liberalization of trade (so-called Doha round). A lot of barriers restricting the macro-economic activity of the state were ignored in response to two crises, namely the financial crisis from 2008 and the pandemic crisis from 2020. Both these events also contributed to the weakening of the ideological position of neoliberalism. Reacting to the pandemic crisis, the European Union launched an aid program financed from Eurobonds, half of which is to be designed for the ecological, social and technological modernization of European societies ${ }^{41}$. Those activities as well as the

41 Cf. Recovery Plan for Europe, https://ec.europa.eu/info/strategy/recovery-plan-europe_en (02.02.2021). 
attempts undertaken by the EU to coordinate climatic policies frequently go beyond the purely market model of integration based on the free movement of people, goods, and capital. Despite these symptoms of erosion of the regime of hyperglobalization, it is hard to speak of a permanent institutional change on the European or global levels.

\section{Conclusions}

The position of the state in the capitalist system is largely dependent on the character of rules making up the world economic order. These rules reflect the interests of the main powers, the configuration of social forces within them, and the predominant economic ideologies. Without any doubt, the international economic system is not the only factor determining the possibility of the state pursuing sovereign economic policy. Nevertheless, it would be difficult to understand changes in the position of the state in a capitalist economy in the long run without taking into consideration the rules operating in the world economy. The argument proposed in this article emphasizes the role of formal and informal institutions in shaping the global order. An analysis of global order from the institutional perspective poses a challenge to some widespread beliefs. Firstly, it is not true that globalization is an inevitable and irreversible process. Globalization understood in this way is a purely ideological category that does not find any support in historical analyses. The rules making up the world order are a product of politics and ideology and their changes are not arranged in any evolutionary sequence. Secondly, it is hardly possible to agree with the view that the world economy is governed by international corporations. Even if the existing rules prefer the interests of large corporations, they are still established and sanctioned by the states. Thirdly, there are no fundamental reasons why the world order could not undergo even very radical changes. The obstacles to such reforms certainly do not include any laws of capitalism or hard requirements of economic rationality. Although it is difficult to imagine a global economy that would not be based on markets, the markets themselves can be institutionalized in a many different ways. The creation of a socially just and ecologically sustainable world economy is, therefore, possible - on condition, however, that a new constellation of ideas and social forces is created. 


\section{Bibliography}

Arrighi G., Silver B.J., Polanyi's «Double Movement»: The Belle Époques of British and U.S Hegemony Compared, «Politics and Society» 2003, vol. 31, Issue 2.

Block F., Capitalism The Future of Illusion, University of California Press 2018.

Cohen B.J., International Political Economy. An Intellectual History, Princeton University Press 2008.

Cox R., Gramsci, Hegemony, International Relations: An Essay in Method, «Millennium - Journal International Studies» 1983, vol. 12, No. 2.

Cox R., Social forces, states and world orders: beyond international relations theory [in:] R. Cox, T. Sinclair, Approaches to world order, Cambridge University Press 1996.

Crotty J., Epstein G., In Defence of Capital Controls, «Socialist Register» 1996, vol. 32.

Eichengreen B., Globalizing Capital. A History of the International Monetary System, Princeton University Press 2019.

Gill S., Market civilization, new constitutionalism, and the world order, [in:] S. Gill, A. Claire Cutler (eds.), New Constitutionalism and the World Order, Cambridge University Press 2014.

Helleiner E., Life and Times of Embedded Liberalism: Legacies and Innovations Since Bretton Woods, «Review of International Political Economy» 2019, vol. 26, No. 6.

Keohane R., After Hegemony. Cooperation and Discord in World Political Economy, Princeton University Press 1984.

Polanyi K., British Labour and American New Dealers, [in:] M. Cangiani, C. Thomasberger (eds.), K. Polanyi, Economy and Society. Selected Writings, Cambridge University Press 2018.

Polanyi K., The Great Transformation. The Political and Economic Origin of Our Time, foreword by Joseph Stiglitz, with a new introduction by Fred Block, Beacon Press 2001.

Polanyi K., Universal Capitalism or Regional Planning, [in:] M. Cangiani, C. Thomasberger (eds.), K. Polanyi, Economy and Society. Selected Writings, Cambridge University Press 2018.

Rodrik D., The Globalization Paradox. Why Global Markets, States and Democracy Can't Coexist, Oxford University Press 2011.

Ruggie J.G., International Regimes, Transactions and Change: Embedded Liberalism in the Postwar Economic Order, «International Organization» Spring 1982, No. 36.

Streeck W., Buying Time. The Delayed Crisis of Democratic Capitalism, London and New York 2014. 